\title{
One size does not fit all: the need for flexibility in policy responses to slow growth
}

\author{
Songqi Wang
}

Correspondence:

wangsongqi@vip.163.com

Institute of Finance and Banking,

Chinese Academy of Social

Sciences, Beijing 100732, China

\section{Springer}

\begin{abstract}
The root cause behind the Chinese economy's slowing down in 2012 lies in a "one-size-fits-all" approach to macroeconomic management. This approach must be abandoned if domestic demand is to be effectively boosted. A superior approach would involve the introduction of policies tailored to the specific needs of the economy. It would call for some combination of fiscal and tax measures to stimulate investments, to enhance the profitability of non-Internet-based economic sectors, to ease lending restrictions, and to increase the growth rate of the money supply. There is little risk of inflation in China in the short term, but deflation is a real threat.
\end{abstract}

Keywords: Macroeconomic management; Credit management; Deflation

\section{Review}

China is facing unprecedented challenges to both its economy and its macroeconomic policies. In July 2012, the Chinese CPI dropped to $1.8 \%$, and PPI has declined for 5 months consecutively. There are no signs of a meaningful recovery to demand for electricity, and exports have grown by a mere $1 \%$. The added value of large industrial enterprises increased by only $9.2 \%$. The total value of new loans is only RMB 540.1 billion, the lowest since October 2011. It is particularly worrying that aggregate fiscal income has grown by only $8.2 \%, 1.6$ percentage points lower than in the previous month, and that the growth rate of tax revenue is down 7.5 percentage points over the previous month. These numbers paint an ugly macroeconomic picture of China, and they inevitably give rise to questions about what is going on-and wrong-with the Chinese economy. The most pressing question to answer is: should we attribute our current predicament to macroeconomic cycles, structural factors, or policy failure?

I have always believed that the key to macroeconomic analysis lies in distinguishing between short- and long-term factors. Solutions to short-term problems require policy instruments, while long-term solutions require structural adjustment, in addition to increased reform and opening up. We must remember that short-term problems are just the temporary manifestations of longer term problems. Thinking in this way will help ensure that we reach the right conclusions about the road forward.

(c) 2015 Songqi. Open Access This article is distributed under the terms of the Creative Commons Attribution 4.0 International License (http://creativecommons.org/licenses/by/4.0/), which permits unrestricted use, distribution, and reproduction in any medium, provided you give appropriate credit to the original author(s) and the source, provide a link to the Creative Commons license, and indicate if changes were made. 
This has not, however, been the mainstream opinion on economic matters in recent times. The going philosophies are typically based on a conflation of shorter and longterm problems. Those who think this way are quick to attribute China's economic difficulties to factors ranging from the defects of the government-dominated economy, to monopolistic state-owned-enterprises, to the need for more reform and opening up. Some go so far as to prescribe constitutionalism, limited government, and economic liberalization for treating what has been ailing China's economy. I beg to differ. Years of researching economic policies have taught me that macroeconomic problems are mostly short term, and that macroeconomic policies are aimed at solving short-term problems. They have, as such, two basic properties: they possess short time horizons, and they are fine-tuning instruments. Fine-tuning essentially tweaks the economy in the opposite direction of its current course of development or what is called a "discretionary decision" in technical parlance. Discretionary decisions can be understood by "Friedman's k-percent rule," attributed to economist Milton Friedman, who proposed it in his disagreements with the post-Keynesian school in 1970s. According to Friedman's rule, so long as the rate of increase of the money supply is kept two points above the annual economic growth rate, regardless of macroeconomic conditions, everything will be fine, no matter where the chips fall. However, it is well known that Paul Volcker, a committed monetarist who preceded Alan Greenspan as the chairman of the Federal Reserve, ditched the Friedman Rule after just 6 months. Why? It is because macroeconomic conditions fluctuate so much that no single rule can apply to every situation. That is the reason that monetary policies in the USA have all been discretionary for the past three decades. No other ideology was ever even considered, and so it was in China as well. On our side of the Pacific, the situation is very similar, as it should be in any market economy. In China's specific case, the problem we are now experiencing is cooling down, and so the goal of fine-tuning at this point is to use policies to heat things up. It is just that simple.

The shrinking of overseas demand is largely due to the debt crisis in Europe and weak economic recovery in the USA, both of which are quite beyond Chinese control. Even though it may seem as though weak domestic demand is caused by restrictions on the housing industry and squeezes on demand for local financing, the real culprit is defective policies. Some have suggested that China's current economic woes are partly attributable to mid- and long-term factors such as tight profit margins and excess capacity within non-banking sectors. While this is true, knowing this fact sheds no light on how to choose the best macroeconomic policy responses. As was noted above, a basic requirement of short-term policies is that they distinguish between short-term and long-term economic factors. We can, therefore, try to understand the feasibility of policy fine-tuning by focusing on two short-term factors: the regulation of the real estate industry and the squeeze on demand for local financing.

Although the "one-size-fits-all" approach to short-term macroeconomic policies is defective, it has nevertheless persisted for years. In the regulation of the real estate industry, for example, measures meant to help curb escalating housing prices in first-tier cities were uniformly applied in cities of all different sizes, including many second- and third-tier cities. But many of these cities not only did not need these measures, but in fact they could ill afford them. The imposition of sweeping policies on them is comparable to medicating an entire family when only one member is ill. 
All local governments in China want to see housing prices rise, because they earn their keep mostly through land leases. Thus, the "one-size-fits-all" approach has effectively deprived many of them of their main source of revenue and is to blame for the fiscal difficulties they have suffered in recent years. To exacerbate the problem, shrinking treasuries undermine the efforts by many local governments to mitigate the negative impact of regulations on the real estate industry. The government in Beijing has included the construction of 36 million units of affordable housing in the 12th 5-year economic plan. These building projects are supposed not only to help low-income households meet their housing needs but also to help more than 30 housing-related sectors by boosting demand for their products. This would have been a perfect plan, except for the for the fact that reduced revenue streams have left these projects unaffordable for many local governments, as the progress report of the construction of affordable housing in the last year and a half demonstrates. In other cities that answered the central government's call to build affordable housing, officials have experienced difficulties in selling the units and recovering investments. The experience of one second-tier city in North-eastern China illustrates this point. Because of the prohibitively high costs of building affordable housing in the downtown area (which would also involve wide-scale demolition of existing structures), the city government had no choice but to have them built far from downtown. But the intended beneficiaries of these buildings are the very ones who can hardly afford the transportation costs living far from the city center would entail, and so many of them have chosen to opt out of moving into the very houses that were intended to improve their living conditions. Furthermore, eligibility requirements for affordable housing entitlements often set the income threshold too low, thus arbitrarily depressing demand. The "one-size-fits-all" approach to policy intervention seems to be a contributing factor to all these problems.

Nothing illustrates the effects of this approach more perfectly than the restrictions that have been imposed on corporate financing beginning in 2010. In 2009, China's central government committed RMB 4 trillion to stimulate the economy in response to the global financial crisis. Much of this money was intended to go to projects funded by government-backed financing agencies. Local governments across the nation became swept up in the short-lived stimulus frenzy. However, this "Great Leap Forward" style economic stimulus likely runs afoul of the natural course of the economy, and the poorest performers among these financing agencies ended up becoming the last to generate bad loans. That said, nearly one third of the nearly 8000 government-backed financing agencies perform quite well and are able to maintain cash flows. But even they suddenly found themselves in deep trouble after restrictive measures were introduced in 2010. This further corroborates the charge that the "one-size-fits-all" approach to macroeconomic policy intervention deviates from the basic laws of a market economy. Now that the economy is cooling, it is high time to make necessary adjustments to the policies governing these agencies and to put the best of them to good use boosting domestic demand. Relaxing the regulations to which they are subject may help deliver China from its current economic difficulties. Right now, China's central government should make clear a number of things. First, local governments should be given greater latitude in exercising the right to make loans. Second, the five largest banks in China-Industrial and Commercial Bank of China, Agriculture Bank of China, Bank 
of China, China Construction Bank, and Bank of Communications-should offer support to these companies. Third, the People's Bank of China should stop using interest rate adjustments, or "punitive" ("differential") reserve ratio requirement hikes, at its branches as a policy instrument for curbing lending increases at the local level.

As banks possess most of the money in China, loosening lending restrictions would be a ready solution to many problems. We can analyze the potential for lending risks and bad loans from two perspectives. On one hand, most Chinese banks are now run as for-profit businesses and as such have an inherent interest in controlling risks, such that they would be unlikely to support local development without reservation even during times of credit growth. On the other hand, some defaults happen precisely because tight restrictions on the lending scale leave some companies and government-backed financing agencies (specifically those which might have survived with greater access to sufficient funds) financially vulnerable and the incidence of bad loans higher. In this sense, banks would essentially be operating to save themselves by helping to save local enterprises in general, government-backed financing agencies in particular, and the local economies by extension.

China is currently undergoing a state and party leadership transition. As such, the government's recent actions can be partially explained by the political cycle. The administration under Premier Wen Jiabao has accomplished many good goals during its two terms, and it should not leave for the next government to do what it can finish itself. In particular, it should try to take aggressive actions to turn the economy around. For example, many have already realized the limitations to the "one-size-fits-all" approach to macroeconomic fine-tuning policies in the realm of real estate restrictions. We should not wait any longer to transition from universal application of uniform lending restrictions across the board toward a narrower application of such restrictions to first-tier cities only, while exempting second-tier, third-tier, and smaller cities. At the same time, the government should increase investment in affordable housing, in part by introducing new taxes targeting real estate development. Officials should expedite progress in property tax pilot programs to restore positive feedback loops in the housing market, which would in turn help increase government income from land leases at the local level. When the government has more money at its disposal, there should be renewed confidence in banks. These developments are also good news for the several dozen other sectors that depend on the real estate industry. Indeed, relaxing restrictions on the real estate industry and on government-backed financing will benefit the overall economy, which may yet prevent from cooling further in the fourth quarter of 2012.

Macroeconomic management is both a science and an art. The difficult part for the government is correctly diagnosing the problems ailing the economy, prescribing the right medicine, and having the political will to take the medicine before it is too late. When we look at other countries, we must realize that conditions in China could not be more conducive towards effective macroeconomic management. First, both the private sector and consumers have money to spend. Second, local governments in China are motivated to grow local economies and are more or less compliant. Third, the dual structure of the economy means there is ample space for continued economic growth. Fourth, institutional reform will free up more space still for economic development. Fifth, there are many tools in the central government's bag for dealing 
with economic difficulties. Sixth, China holds foreign reserves valued at USD 3 trillion, which may be tapped in case of an emergency. The list goes on. The so-called challenging situation facing the Chinese government really boils down to a question of proper diagnosis and correct prescription.

\section{Adopting appropriate fiscal stimulus policies}

Stimulating domestic consumption should be a long-term rather than a short-term policy. This is because consumers' demand (among both rural and urban populations), which accounts for most of domestic consumption, cannot increase more than disposable income does. Other factors beside disposable income also affect consumer spending, for example, consumer expectations and social context. Therefore, boosting consumer demand does not fall within the purview of short-term stimulus policies. Now that overseas demand for Chinese products is weakening, the only ways to quickly relieve the economy are increasing investments and adding more government projects. International factors aside, three domestic factors contributed to our current economic difficulties. The first was tight restrictions in recent years on the real estate industry, which have dealt a harsh blow to output and sales for the 30-plus sectors that are closely linked to the real estate industry. The second was tight restrictions on government-backed financing agencies that were introduced in 2010, following a barrage of aggressive spending in 2009. The third was the postponement and/or stoppage of many large central government-funded infrastructure projects, including construction on railroads, highways, and airports. For the moment, it seems that restrictions on the housing industry will likely stay in place for some time, but it may be possible to relax restrictions on government-backed financing, and for infrastructure projects that have been put on hold to be resumed. Those in China who disagree are usually concerned with local governments' debt capacity and the prospects for cost recovery from transportation and other infrastructure projects. But these fears are misplaced. On one hand, when government-backed financing agencies with highgrade capital are used, both liquidity and debt-repayment capability are more or less assured. On the other hand, it is unwise to jump to hasty conclusions regarding the cost-effectiveness of transportation infrastructure projects, which are best evaluated over the long term. But even if, in the worst-case scenario, projects funded by government-backed financing organizations and infrastructure construction projects (railroads, highways, and airports) should all fail completely, spill-over returns these efforts generate may flow into other economic sectors.

\section{Loosening policies}

The most important component of any short-term stimulus is the relaxing of the money supply. So far, interest rates have been lowered twice. But this is far from enough. Moreover, the reserve deposit ratio is currently too high at $20 \%$. It should be $17 \%$, a rate that would have raised the amount of money available for lending at commercial banks to RMB 2500-3000 billion. M2 can also grow at the expected target rate of $16 \%$. As for monetary policy, the central bank should amend or abandon the use of interest rate adjustments or "punitive" (or "differential") reserve ratio requirement hikes which local branches have been required to make in the last 2 years. This 
would free employees up from the monotonous task of monitoring these numbers from around the country. Instead, local Banking Regulatory Commissions should be allowed to determine the proper scale of lending for commercial banks by applying the set of relevant formulas for calculating liquidity, reserve ratio requirement, and risks devised by the central Banking Regulatory Commission. The central bank should focus on combating money laundering and managing in-flows and out-flows of foreign currencies and payments and receipts for cross-border transactions.

Quantitative easing and lifting of credit caps will provide the necessary conditions for commercial banks and borrowers to do their part to help the economy grow. It is still in the interest of the central government to improve tax policies in order to create internal growth stimuli for economic sectors that produce material outputs. For instance, the tax burden on small businesses should be reduced, and technology firms, especially those which create original products, should be exempted from taxes altogether. This would encourage private investment toward companies and projects engaged in technological innovation. If we did this, the foundation of China's industries will undergo considerable improvement within 5 years. In addition to preferential tax policies for small businesses and technology companies, corporate tax rates should be cut for private enterprises of all kinds. The Chinese economy has now entered a period of cost increases, and profit margins for most companies in nonbanking sectors are generally quite low. Banks, by contrast, have been extraordinarily profitable. The government should try to rectify this situation with appropriate policies to channel more financial resources toward non-banking sectors. History has taught us that if the profitability of the financial sector is substantially higher than that of any other sectors, especially industrial sectors, the economy will sooner or later lose momentum. If our tax policies and other stimulus measures are not backed by sound science, all these years of lip service to structural adjustment and development according to a scientific outlook will have been hot air. This time of economic downturn is the opportune moment for China to give its non-banking sectors a shot in the arm by making the right changes to the country's tax structure.

\section{Conclusion}

The central bank has been printing too much money for some time now, so much so, in fact, that it has well nigh become a consensus among those in the know that an oversupply of money has been the real reason for the 30-year-long "economic miracle." Proponents of this view include both laymen who write prolifically and uninhibitedly, and senior scholars, some of whom are industry veterans, and some of whom have held key posts in China's central bank. When the economy began to head south, these same people were unanimous in opposition to the central bank's planned adoption of quantitative easing policies and regulatory commission's planned lifting of restrictions on local banks to lend to government-backed financing agencies and large projects. To them, China was repeating the mistake flooding the market with money in order to stimulate the economy.

I have always held a different belief.

What, after all, is money? It is neither an illusion nor a thin veil but an instrument for trade. Money is one of the most important elements in a commodity economy. 
Money in circulation, whether originating from the balance sheets of commercial banks or through foreign reserve purchases by the central bank, represents a certain amount of commodities and labor activities. Therefore, an economy runs well only when the money supply is commensurate with the economy's demand for money. This means there should be neither a surplus nor a deficiency of money in circulation. Surpluses are usually indicated by CPI and PPI, while signs of deflation would indicate a deficiency. China's current M2 growth rate of $13.6 \%$ still falls short by 0.4 percentage point of the target rate set by the central bank (14\%), and the Chinese economy's growth is already slowing. This should leave little room for skepticism about the appropriateness of quantitative easing policies. The central bank's historical data show us that 8 percentage points higher than GDP would be quite reasonable for M2. Since China's GDP growth was $7.8 \%$ for the first 6 months of 2012, the target M2 rate should be $15.8 \%$.

Competing interests

The author declares that he has no competing interests.

Authors' information

Wang Songqi is the deputy director of the Institute of Finance and Banking, Chinese Academy of Social Sciences. His research focuses on macroeconomics, monetary policy, financial reform, business banks, globalization, rural finance, and venture capital.

Received: 11 September 2015 Accepted: 11 October 2015

Published online: 08 December 2015

Submit your manuscript to a SpringerOpen ${ }^{\odot}$ journal and benefit from:

- Convenient online submission

- Rigorous peer review

- Immediate publication on acceptance

- Open access: articles freely available online

- High visibility within the field

- Retaining the copyright to your article

Submit your next manuscript at $\boldsymbol{~ s p r i n g e r o p e n . c o m ~}$ 